\title{
The role of universities for workplace innovation: A Turkish case
}

\section{Hayal Köksal}

\begin{abstract}
Universities have three essential functions. One is educational and other is about generating knowledge and technology. The last one is related to the bridge between the theory and practice that is being practically engaged to the society that is generally called "Service". In many of them, to educate the citizens and citizen-leaders for the society is a much more important mission then the latter. They do this through their commitment to the transformative power of a liberal arts and sciences education. While focusing on the educational issues of students, university administrators should also take into consideration the training needs of their own administrative personnel, since they are among the fundamental internal customers of the university. Creating an innovative workplace for all is essential at a contemporary university, since it is accepted as one of the role model workplaces within society. This paper emphasises the crucial need and the steps of in-service training programmes for administrative personnel, which contributes to the educational and managerial quality of higher education institutes. As a sample case, an inservice training programme is shared for the training needs of the administrative personnel of a Turkish State University, located in Istanbul, after conducting a detailed needs analysis. Following the response of the sample university to the research findings, the paper concludes with reflections on alternative institutional structures, based on Quality Circles / Imece Circles.
\end{abstract}

Keywords: University personnel, Programme development, Needs assessment, In service training, innovation, Village Institutions, Quality Circles, İmece Circles 


\section{Introduction}

Organisations and their human resources, as well as their needs, are constantly changing and both must develop new skills to maintain effective operation. In a period of recession and rapidly changing technology, it is imperative for organisations to create a flexible and adaptable labour force with the competency to use new technology and methods. As Laird (1985) stated, "A training need exists when an employee lacks the knowledge or skill to perform an assigned task satisfactorily."

The training and development of personnel is an issue that has to be faced by every organisation. The amount and quality of training carried out varies enormously from one institution to another. In recent years, the topic of in-service training, along with the concept of human resource management, has attracted more attention of administrators and employers. Several studies have shown that organisations vary greatly in their commitment to training activities. Some of the major corporations see themselves making a continuing investment in their human resources, though some still have the tendency to consider training as an unnecessary expense or waste of time. The latter meets their needs for training in an ad hoc and haphazard way. Training in these organisations is more or less unplanned and unsystematic. The others set about identifying their training needs, then design training activities around this, carry out the training, and finally assess the results of training. Such organisations engage in a systematic approach to the training and development of their employees.

What is the situation of the personnel (employees) working in universities? The main functions of higher education and universities are mainly two-fold. One is education; the other is technology and research, which are delivered to society as services. However, there appears to be a problem. Do universities provide education and training only for students, or for all internal and external customers? In other words, do they ignore one group of inner customers, like administrative employees, while ornamenting the students with modern knowledge? After working more than thirty years at various universities of Turkey, and working with total quality issues at schools, the author wants to focus on the training needs of administrative personnel who work very close to students and instructors in their daily routine. That kind of closeness, and their weak points, affect directly the quality level of faculties. Therefore, one of the main missions of university administration should be providing training for all workers in addition to faculty staff.

\section{Universities as Change Agents and Quality Creators}

Universities are an important part of societies. Their existence brings a great change to their surroundings. The university was, without doubt, a social innovation of great magnitude. It made it possible to create a market of wise men, technologists and instructors among the political and ecclesiastical powers. The responsibility of universities is to create, store and transmit knowledge through teaching, investigation and publication. Thus, they act as the change agents of communities. Universities contribute to the development of countries in a traditional way by training professionals, and by being at the centre of the creation and transfer of knowledge per excellence. In many regions, the importance of the university as a motor of development is noteworthy. Its contribution to human capital, technological contribution and cultural change is great (Klann-Delius \& Somerville 2001).

The study of university contribution to development is recent. For instance, the following words are heard often for universities; objectives of the Institution, indicators, public sources of finance, private sources of finance, evaluation, quality management, participation, competition, internal competition, collaboration, incentives and control. These terms entered Turkish university life after the Total Quality Management (TQM) application trials into them after 1995. It is important to order that set of words, and to balance those concepts. There are also some contradictions about the current running of universities like; academia 
versus bureaucratic staff, public management versus private management, and research versus teaching focused university, etc. Settlement of all these arguments will bring more quality and productivity to universities.

Another surprising contradiction in the proposals of experts concerning the abovementioned quality issues is taking place at the initial step of quality. While determining the customer clusters, they fail to include the university personnel/employees into the training loops (Köksoy 1998:8). Those people, those key factors of the working population of a university, are constantly kept out of the interest and training issues within that universal training agent: the university. It is surprisingly interesting. In order to eliminate the weak sides of the employees, a carefully planned needs assessment is essential. With the development of technology, some responsibilities have shown great change. For instance, typists do not exist in any workplace anymore. Computers are the main vehicle of secretaries. Some new needs appeared because of the changing world. People need to learn how to manage their time, how to deal with workplace conflict and how to manage new risks. All those issues seem to be the in-service training needs of the personnel. In the following section, this issue will be investigated.

\section{Significance of In-Service Training at Universities}

In-service training has long been a method for the improvement of instruction in institutions of higher education. Although in-service training has played a significant role in academic life, personnel work has not utilised such activities. Statistics have proven that, the rate of the participants among university employees in in-service training activities, by the distribution of government agencies and establishment groups, is approximately four percent. In 1982, the State Institute of Statistics (DİE, 1992), and The State Personnel Presidency collaborated to reveal statistical data on pre-service and in-service training activities of state establishments and foundations. According to the first publication, called "Statistics on Training in State Institutions", 278,000 people from government agencies and establishments participated in inservice training activities in 1992. Only one percent of the trainees were actual university employees.

Each individual possesses a unique blend of skills and knowledge, personality, interests, and preferences. It is to an institution's advantage to maximise the development and the utilisation of its human resources to ensure employees' satisfaction and productivity. As has been clearly understood, training: especially inservice training of human resources of those working at universities, has been ignored for a long time. The author's University is one of the schools, which has an in-service training department, but it does not contain a well-designed programme. The so-called in-service training sessions are termed as "Monthly Lecturing Sessions" at the beginning of each year, but since they are not based on the needs of the employees, they are not taken into serious consideration by the employees or the administrators.

The establishment of comprehensive programmes in in-service training can contribute effectively towards solving some of the problems facing university administration. In-service training for employees should be directed toward professional upgrading of each staff member as an individual, and the increased competence of the staff (Truill \& Gross 1970:68).

Universities are the laboratories for the future. In this role, they are a major and competent leader in society. A systematic approach to training and development should follow a logical sequence of activities, starting with the establishment of a policy and the resources to sustain it, followed by an assessment of training needs, for which appropriate training is provided, and, ending with some form of evaluation and feedback.

In the following study, the author assessed the in-service training needs of the employees working at a Turkish State University according to their perceived needs, and according to the academic and nonacademic administrators' point of view. After the "needs assessment phase", an in-service training 
programme was proposed, in order to meet the established needs. She chose Marmara University as the target, because she graduated from the Faculty of Education of that university in 1995, she worked as a co-ordinator for it for six years, and she retired from there in 1999. She thinks that she owes that kind of support to her mother workplace. From then on, it will be mentioned as 'the university'.

\section{Problem}

As the result of changing technology, organisations are finding it increasingly difficult to fill some of their human resource needs with already trained employees. Out of this situation, they are finding it necessary to do more of their own training, and to develop talent from within the organisation. "In-service training has long been an effective method for the improvement of work to attain the goals of the organisation" Taymaz states (1981:21). Although major industrial organisations spend enormous amounts of effort and money for the training needs of their employees, the in-service training of the personnel working at schools, particularly at universities, has been mostly neglected.

The establishment of a comprehensive programme of in-service training can contribute significantly toward solving some of the problems facing universities, and more specifically in the administrative personnel area. Due to the reasons mentioned above, the Seventh Section of the State Personnel Law, No.657, has defined the regulations of in-service training activities of personnel working for State Establishments and Foundations under the heading of "The Training of State Personnel ". According to the Article 214 of the same Law, "An in-service training programme, which aims at increasing the efficiency of the State Personnel, improving their productivity, and preparing them for higher level positions, is conducted through the regulation prepared by the State Personnel Presidency and the related organisation. Article 215 recommends that each organisation establish a "Training Bureau" for the organisation, which includes the implementation and evaluation of training programmes for the training needs of their staff. The Higher Education Law, No.2547, also has similar rules related to in-service training.

When the situation was analysed at Marmara University, one of the largest universities in Turkey, in accordance with the rules mentioned above, it was understood that no well-planned in-service training programme for the employees (secretaries, typists and other employees) existed, except for a few explanatory sessions about the recent changes in the rules and regulations related to the administration (1994-1997).

The problem, therefore, appears to be twofold;

- The investigation of the in-service training needs of the employees working at the university.

- The establishment of an appropriate programme that would meet the needs of the employees.

\section{Purpose}

This study attempted to develop an in-service training programme, after the assessment of the in-service training needs of employees working at the university.

In-service training is a multidimensional phenomenon, with numerous variables such as employees, academic and non-academic administrators, that makes it necessary to take into consideration the perceptions of each position on the determination of their training needs. Additionally, the effects of independent variables such as; age, sex, educational level, work experience and type of job the employee performs will be investigated in order to better establish their training needs. In summary, the aim of that study was to identify the in-service training needs of the employees at the University and to develop an inservice training programme. 


\section{Research Questions}

The primary focus was on the identification of the in-service training needs of the employees and on the development of a programme, which would help the administrators bring in an over-all solution to the problems. The following questions were examined in the course of this study:

\section{A. Questions and Sub-questions Related to the Needs Assessment:}

1. Which in-service training areas and courses are perceived as important for employees by employees, academic administrators, and non-academic administrators?

2. Are there any significant differences in the perceptions of employees, academic administrators and non-academic administrators about the -service training needs of employees?

3. Which training methods do the employees prefer while attending the courses?

4. Is there a consensus among employees, academic administrators and non-academic administrators on the instruction time of the in-service training courses of the employees?

In addition to the above main research questions, the following sub-questions will also be answered:

- Do the perceptions of employees on the areas and courses vary according to age?

- Do the perceptions of employees on the areas and courses vary according to sex?

- Do the perceptions of employees on the areas and courses vary according to educational background?

- Do the perceptions of employees on the areas and courses vary according to work experience?

- Do the perceptions of employees on the areas and courses vary according to type of job performed?

\section{B. Question Related to the Programme Development:}

1. What kind of in-service training programme may be developed for the employees of the university in the light of the findings of the "Needs Assessment"?

\section{Method of Data Collection}

Selection of the subjects: In that study, two populations were under consideration: administrators and employees. "The administrators' group" consisted of academic and non-academic administrators working in different faculties and offices of the university, and they were in close contact with employees. "The employees' group" consisted of administrative personnel such as secretaries, typists, officials, librarians and custodians. The medical and technical staff were excluded, as the researcher believed that an expert in those fields should assess their needs. Also excluded were those who have been working at the university for less than a year, under the assumption that they had just had "Basic and/or Orientation Training".

Since the purpose of that study was to develop an in-service training programme for the needs of the employees of the university, all the employees, academic, and non-academic administrators: excluding medical, technical and academic staff, were taken as the subjects. The subjects were estimated as 141 academic, 162 non-academic administrators and 680 administrative personnel. Of this overall population, the margin of error was $10 \%$ as these questionnaires were not suitable for analysis or were not returned. Thus, the population included 609 administrative personnel, 148 non-academic administrators, and 128 academic administrators.

The "Employees' Group" consisted of five different types of professions: officials (331), secretaries (64), typists (89), librarians (29) and custodians (105). The "Academic Administrators' Group" (128) included the Secretary General, Deans, Assistant Deans, Directors of Institutions and their assistants, Directors of Schools for Advanced Vocational Studies, and their assistants, Heads of Departments, and Heads of Social and Scientific Disciplines. Office Directors, Executive Secretaries to the Faculties and to the Schools for 
Advanced Vocational Studies, Section Officers, Accountants, and Chiefs constitute the "Non-academic Administrators' Group" (148).

Instruments: In that study, two sets of questionnaires were utilised for data collection purposes in the "needs assessment" phase. One was used for both groups of the administrators (academic and nonacademic), and the other for the employees. The questionnaires, developed by Gedikoğlu in 1989, were modified and adapted by the researcher. First, a broad review of literature and regulations prepared by the related body of government (The In-service Training Department of The State Personnel Presidency) concerning in-service training was examined. Secondly, some corrections and changes were made. After consultation with various experts in the fields of "adult education" and "in-service education" in Istanbul and Ankara, four judges (academics) were asked to check the content and determine the face validity of the questionnaires before a pilot study would be conducted. After having made the recommended changes, the judges agreed that the instruments could serve the purpose, and they suggested that the researcher conduct a pilot study.

Thus, a pilot study was conducted $(\mathrm{N}=35)$ in one of the faculties of the university. After the application of "Test-retest" technique, the reliability of the instruments was computed by utilising the reliability subprogramme of SPSS (Nie 1975:58), and it was found to be 0.92, indicating high reliability. The results of the pilot study were also discussed with the experts, and the questionnaires were given their final form.

Each questionnaire consisted of three parts:

1. Demographic characteristics of the respondents,

2. Seventeen in-service training areas and five teaching methods (the teaching method took place only in the questionnaire form of the employees).

3. Nine In-service training courses, and their preferred times; "During Work" or "After Work".

The Employees Questionnaire: The first part of the questionnaire aimed at identifying the demographic characteristics of employees (age, sex, type of job, educational background and work experience). Thus, necessary information would be gathered to draw a profile of the employees, and data would be used to find answers to the sub-questions of the needs assessment part. In the Second Part, the respondents (employees) were asked to identify the extent 17 areas on five-point Likert type questions ranging from a "Very Important" specification" to "Definitely not important". The options were weighed from five to one. They were asked to define the training methods as well. Part 3 included nine courses, and their perceptions of their in-service training needs were asked through a one to five Likert scale as mentioned above. They were also asked to identify the instruction time of the courses.

The Administrators Questionnaire: The first part consisted of only the options concerning the posts of the academic and non-academic administrators. In the Second Part of the questionnaire, the administrators were asked to define the in-service areas related to the jobs of their employees through a one to five Likert scale. The ratio of the options was five to one, as mentioned earlier. The last part was the same as the employees' form. 


\section{Method of Data Analysis}

In the study, the data related to the in-service training needs and demographic characteristics of the employees of the university were processed at the Computer Centre of the university. The researcher used the following tools to analyse the data:

- the frequency distributions and percentages",

- "t-test" (when independent variables have two categories and dependent variables are continuous),

- "one-way analysis of variance (ANOVA)" (when independent variables have more than two categories and dependent variables are continuous),

- $\quad$ and after ANOVA test, to see where the differences occur; a "Post hoc"- Student-Newman-Keuls test (S.N.K.) of SPSS (Statistical Packages for Social Sciences / .5.0), and

- "chi square test" (when the whole variables are categorical) (Gay 1987:420).

In analysing the First Part of the questionnaires, "frequencies and percentages" were used to describe the demographic characteristics of the respondents. The same statistical procedure was applied to find out answers to the questions related to the "Teaching methods of the subject matters" (Question 3), and the "Instruction times of the in-service training courses" (Question 4). Furthermore, in order to test if there were any significant differences in the perceptions of the employees, academic administrators and nonacademic administrators on the "Instruction time of the courses", the chi-square test was used.

In determining the degree of importance of the subjects' job specifications and the courses according to the perceptions of three groups of subjects (Question 1); the means, standard deviations and percentages of each item were used. In order to identify if there were any significant differences in the perceptions of the employees, academic administrators and non-academic administrators of employees' in-service training needs (both areas and courses) (Question 2), one-way Analysis of Variance (ANOVA) was used. According to Gay (1981:321), in a study involving three groups, the ANOVA is the appropriate analysis technique.

One-way Analysis of Variance was also used to see the differences between the perceptions of employees concerning age, educational level, work experience and type of job performed (Sub-Questions). In the analysis of variance, an overall $F$ test, if significant, simply indicates that there are significant differences somewhere in the data. To test hypotheses, however, more or less controlled and precise statistical tests (Post Hoc) are needed (Kerlinger 1979:232). Thus, the researcher is able to know which differences contribute to the significance. In order to realize this, the Student-Newman-Keuls (S.N.K.) test was used. It is a multiple comparison procedure that arranges the group means from the smallest to largest and sets the ranges that is used to test for a significant difference between means on the basis of a number of steps between the two means being tested.

The t-test was used to test if there were significant differences between the perceptions of the employees concerning sex (Sub-Question). The t-test is used to calculate the degree of significance of two means at a selected probability level. The t-test makes adjustments for the fact that the distribution of scores for small samples becomes increasingly different from a normal distribution as sample sizes become increasingly smaller (Gay 1987:428). 


\section{Discussion of Results}

\section{Demographic Characteristics of the Participants:}

Employees: According to the results (1997), the majority of the employees working at the university were young; 54.5 percent of them are between the ages of 30 and 39, with an experience of 6-15 years (58.2\%). It was interesting to note that, more than half of the employees were females (56.8\%), and nearly half of the employees were high school graduates $(55.2 \%)$. The other were faculty graduate and elementary school graduates. The majority of the employees were officials $(54.3 \%)$ performing office work. 17.1 percent were custodians, 14.5 percent are typists and 10.5 percent were secretaries. The remaining 4.6 percent were librarians.

Administrators: Since the employees constituted the focal point of the study, the demographic characteristics of the administrators were not taken into consideration, except for their positions.

\section{The perceptions of the Subjects:}

The findings revealed that in general there was some consistency among the perceptions of the groups. For instance, each of the first ten areas took place within the first ten important areas of each party. In rank ordering of the importance of the 17 areas, it was found that the three groups agreed on the first most important area (Improving the Oral and Written Forms of Turkish Effectively and accurately). Employees and academic administrators agreed on the second one (Learning the Administrative Regulations, and their Application) and the third one (Learning the Ways of Maintaining Discipline, Safety and Order at Work). The perceptions of the employees and non-academic administrators showed similarities on the areas 5 (Learning Self-improvement at Work), 9 (Learning How to be Productive and Harmonious in Group Work) and 10 (Improving Oral and Written Communication within the Organisation). Academic and non-academic administrators showed significant differences in all areas, except for the first one.

On the other hand, the perceptions of the subjects concerning the in-service training courses revealed statistically significant similarities on the third, fifth and ninth courses. All the groups placed the "Time Management Course" as the second most important, "Executive Secretary" as the second least important and the "Typing Course" as the least important. Although, employees and non-academic administrators shared the same perceptions on course 4 (Computer) and course 8 (Public Relations), academic administrators demonstrated significant differences.

\section{Teaching Method Preferences of the employees:}

The results of the "Frequency Distributions and Percentages" revealed that employees preferred "Lecture" method for nine and "Learning by Practicing" method for seven of the areas. They preferred "Group Work" method only for one area (Learning How to be Productive and Harmonious in Group Work). They did not prefer the other two methods ("Question and Answer" and "Case Study") for any of them.

\section{Perceptions of the Subjects on the Instruction times of the Courses:}

The three groups of subjects (academic administrators, non-academic administrators and employees) agreed on six courses to be given after work. These are; "Turkish", "Time Management", "Public Relations", "Foreign Languages", "Executive Secretary" and "Typing" courses. The perceptions of the participants demonstrated significant differences on "Computer", "Behaviour and Appearance" and "Office Management" courses. In general, employees perceived those courses as "During Work" activities, except for the administrators. 
The Associations between the Perceptions and Demographic characteristics of the Employees:

In terms of demographic characteristics, employees showed differences in the perceptions of the in-service training needs of themselves. Statistically significant differences were found among the perceptions of the employees on twelve areas and six courses, concerning age. For most of the areas the younger employees indicated "more important" in-service training need, whereas, the courses were stressed as the most important needs by the oldest group of employees. Those who were between 30 and 39 did not perceive the in-service training as important as the other age groups did. That might reflect that young employees were facing difficulties with their jobs, and their older colleagues were aware of their needs for in-service training.

There were significant differences between the employees' perceptions areas and one course concerning their sexes. Female employees perceived those items as more important needs for employees than the male employees did. They agreed on the other nine areas and eight courses.

Two-year higher school and university graduates perceived a higher importance in most of the areas and courses than elementary or Jr. High school graduates did. Employees with "higher education level"especially, those who have degrees- are more aware of the in-service training needs of the employees working for the university.

On the other hand, the results of the statistics revealed that no significant differences were found between the work experiences of the employees and their perceptions about eleven areas and six courses. Level of experience was not found to be a significant variable in their perceptions about those points. For the remaining areas and three courses, the experience-groups shared their feelings. In summary, as they gained more experience, they considered those in-service training needs as having more importance for the employees.

In contrast to work experience, all of the employees with different type of jobs perceived differently the importance of the in-service training. Typists, librarians and secretaries were the ones who perceived most of the areas and in-service training courses as being "Very Important". Officials and custodians perceived none of their areas as important. Officials considered the "Computer Course" as the most important one, and the custodians thought that "Turkish Course" was the most important one. There existed no significant differences among the perceptions of the five job groups of the employees on the "Executive Secretary" and "Behaviour and Appearance" courses.

\section{Programme Development}

The improvement of in-service training in organisations and the effectiveness and efficiency of employees, requires careful needs analysis and planning of training design. In other words, the goal of the in-service training programme is to improve the performance and productivity of the present, experienced employees of the University, by decreasing the deficiencies through training in four months' time. This goal sought by in-service training is directly related to the needs of the personnel and basic objectives of the organisation. All employees should receive appropriate opportunities to improve their job performances. In that study, the perceptions of the academic administrators were accepted as the major criterion for the in-service training needs of the employees. However, the perceptions of the other two parties: non-academic administrators and employees, were taken into consideration, to some extent. in the light of the findings, three in-service training courses were eliminated and six in-service training courses and related seventeen areas appeared to be the in-service training needs of the employees for the university. The programme would be realised through these in-service training courses: "Turkish", "Time Management", "Computer", "Behaviour and Appearance", "Public Relations" and "Office Management “. 
For each of those courses, the researcher listed a series of objectives through the needs analyses. The inservice training areas were expressed as the objectives of the programme because they were the expected behaviours of the employees as the result of this in-service training programme. After having completed the in-service training programme, employees of the university would reach the following programme objectives. The employee who finished that programme successfully would be able to:

1. Improve in oral and written forms of Turkish effectively and accurately.

2. Recognise better ways of oral and written communication within the University.

3. Know how to be productive and useful at work.

4. Develop self-improvement at work.

5. Know how to be productive and harmonious in group work.

6. Learn how to be creative and investigative at work.

7. Know how to motivate themselves to work harder.

8. Be familiar with the practical use of innovative technology (e.g. computer and fax).

9. Understand the administrative regulations and their appliance.

10. Interpret the ways maintaining discipline, safety and order at work.

11. Rearrange the relations between the subordinates and superiors in accordance with modern human relations.

12. Comprehend the ways of dealing with disagreements at work.

13. Learn self-evaluation and self-control.

14. Be familiar with the ways of "filing" and styles of "corresponding.

15. Develop good leadership skills.

16. Learn the use and the maintenance of the office equipment.

17. Be familiar with the activities to improve their social, cultural and artistic sides in order to mingle with the other people.

\section{Design of the Programme:}

In order to realise those objectives, and match them with the desire of the employees, the abovementioned five in-service training courses, would be satisfactory. The "Computer Course" was considered as a component of the "Office Management Course" since it was only needed by those who performed office work. On the other hand, the "Public Relations Course" was included in the "Core Course" which holds the obligatory subjects by the Laws, such as; "The Principles of Atatürk", "The History of Turkish Revolution","First Aid" and "Civil Defence". Because "Public Relations" is considered one of the basics of a contemporary organisation. Thus, in order to accomplish the programme goal, in-service training programme would be realised through the following five in-service training courses:

- Turkish

- Time Management

- Behaviour and Appearance

- Office Management

- Core

Those courses were also divided into different segments to meet the differing in-service training needs of the employees who had significantly different characteristics concerning educational background and type of job they performed. Each main course consisted of; a) the course goals and objectives, b) the course content, c) the course Implementation and d) evaluation of the course.

The major elements of the course design generally contain: the participants, the content, the trainers, needed resources, location and facilities, the training methods, scheduling, administration and budgeting and measurement of the trainees' achievement. Each of these elements were clarified in the study. In the 
light of the findings, the researcher, including 17 in-service areas, developed a 40-hour-programme and six in-service training courses (See the figure). The necessary additions, which were recommended to be included in any in-service training programme to be conducted in Turkey by the in-service training regulations of the State's Personnel Institution, were applied. The proposed programme, that was based on the results of a needs analysis of all employees and the perceptions of the administrators of the needs of their employees, was designed to respond to the changing professional needs of administrative employees by offering activities to improve their productivity.

\section{Recommendations}

On the basis of the findings of that study, the following can be recommended for further studies on inservice training needs of the university personnel:

1. This study only surveyed the employees of Marmara University as a representative of Turkish State Universities. Therefore, for further studies, it may be wise to survey the other universities (state and/or private) by using different techniques, such as; interview or observation in addition to the questionnaire forms of this study to be able to make comparisons among different universities.

2. Universities could have a great role in supplying the training facilities. They could support other institutions and organisations in developing and setting up in-service training programmes. Related professors in the universities could help to develop such training programmes and provide trainers and training aids. Then, it becomes the responsibility of these institutions / organisations to send their educators and administrators to participate in the training programmes and make training a compulsory pre-condition of employment.

3. Many administrators and even educators look upon in-service training as a stepping-stone rather than as a motivator and developing factor. Therefore, the government and the high-level administrators of the organisations should consider in-service training as an important section of the educational system.

4. In this study, the programme was designed only for the administrative employees (typists, secretaries, officials, librarians and custodians). Maybe another study can include other employees such as technical or medical ones.

5. The implementation and evaluation phases of the study may also be investigated more deeply in different studies.

Further studies are recommended to all universities to determine the needs of their customers.

\section{Conclusion}

Development and increase of the quality level of a country depends on the quality of universities. They are the main change agents of a community. Quality improvement efforts cannot be partial. Wholeness is necessary. Therefore, if the instruction and administrative issues are the main concerns of any institution, all members should get the advantage of all innovative developments within the institution. This is the main responsibility of top managers. In this research, the main target was the employees, in another one it might be any other working group. If one would like to talk about workplace innovation, it must be open to all customer groups.

The research was conducted by the author as part of a $\mathrm{Ph} \mathrm{D}$ dissertation. A programme of staff training and development was recommended in 1998, but the University administrators declined to proceed. Even though the author retired from the university in 1999, she continued working at various outstanding Istanbul universities. After 2000, she has focused her studies on alternative institutional structures and Quality Circles (QC). She localised that methodology to Turkish settings and designed a new one called Imece Circles. Following the response of the sample university to the research findings, the paper 
concludes with reflections on alternative institutional structures, based on Village Institutions and Quality Circles / İmece Circles.

There has been a long tradition of Village Institutions in Turkey, which were first established by Ataturk, as part of his vision for building a modern Turkey, after the Ottoman Empire and the First World War. This offers an alternative, practically oriented, model of education, including Higher Education and Teacher Education. Arising from this has been recent substantial work in Turkey with Students' Quality Circles, also known in Turkey as İmece Circles. This can also be seen as building on foundations of Quality Circles in Japan, which were then transposed to the context of schools in India, and became the basis for an international movement, concerned with aspects of Total Quality Management, and with a focus on Quality as Empowerment.

In Turkey, Quality issues have gained importance for universities recently. The Higher Education Council has started some training programmes for administrative personnel starting from Deans. That is an initial positive point for all developing countries like Turkey. We may hope to see a re-invention of the modern university, taking account of the role of the university as a knowledge workplace. Many bureaucratic universities, often preoccupied with New Public Management, have neglected the learning and development needs of their own employees, thus damaging the effectiveness of the university as a whole. There are alternative ways forward. The objective should be having qualified and outstanding global universities, instead of having hundreds of low-quality higher education schools. This will bring quality to education.

\section{References}

Akyıldı, İ.1994. A Study of In-service Training Activities in Selected Turkish Industrial Organizations, Unpublished M.A.Thesis, B.U., Istanbul.

Başaran İ. E., 1966. Hizmet-içi Eğitim Araştırması (In-Service Training Research), MEB Eğitim Birimi Müdürlüğü Yayınları (Ministry of National Education Publications), Ankara.

Bloom B., 1956. Taxonomy of Educational Objectives-I. The cognitive Domain, Longman, London.

Bursalığlu Z., 1975. Eğitim Yöneticisinin Yeterlilikleri (Sufficiency of Educational Administrators), A.Ü.E.F. Publications, No.51, Ankara.

Cole G.A., 1988. Personnel Management, DP Publications Ltd., London.

DİE 1992. Kamu Kurum ve Kuruluşlar Hizmet Öncesi ve Hizmet-içi Eğitim İstatistikleri (Statistics of Pre- and In-Service Training Programs of the State Organizations), T.C. Başbakanlık Devlet İstatistik Enstitüsü (Institute of Statistics of Turkish Prime Minister Office, Ankara.

Gay L.R., 1981. Educational Research, Bell and Havel Co., LA.

Gedikoğlu T., 1989. Gaziantep Üniversitesi İdari personelinin Hizmet-içi Eğitim İhtiyaçları (In-Service Training Program Needs of G.U.), Gaziantep.

Karasar N., 1986. Bilimsel Araştırma Yöntemi (Scientific Research Method), Bilim Publications, Ankara.

Klann-Delius G. \& Somervill J. 2001. “Opening Talk of the Dean” (Deans' European Academic Network, Third Annual Conference Proceedings, Berlin, 8-10 October.

Köksal H., 1997. A Proposed program for the In-service Training Needs of the Employees Working at M. U., Unpublished Ph.D. Dissertation, Gaziantep University, Gaziantep.

Köksoy, M. 1998. Yükseköğretimde Kalite ve Türk Yüksekögretimi için Öneriler (Suggestions of Quality at Universities and Turkish Higher Education), İstanbul Kültür University Publications, No: 2, İstanbul.

Nie N. H., Hull J.H., Jenkins J.G., Steinbrenner K. and Bent D.H. 1975. Statistical Package for the Social Sciences (2nd Ed.), Mc Graw - Hill, New York.

Taymaz H., 1981. Hizmet-içi Eğitim-Kavramlar, Illkeler, Yöntemler (In-Service Training: Concepts Principles Methods), AÜİEF Publications, No. 94, Ankara. 
About the author

Dr Hayal Köksal is an experienced university teacher in Turkey and Cyprus, an NGO leader and activist. She is Director General for Turkey of the World Council for Total Quality and Excellence in Education (WCTQEE).

hayal@hayalkoksal.com 